\title{
Benchmarking protocols for the metagenomic analysis of stream biofilm viromes
}

\author{
Meriem Bekliz ${ }^{1}$, Jade Brandani ${ }^{1}$, Massimo Bourquin ${ }^{1}$, Tom J. Battin ${ }^{1}$, Hannes Peter ${ }^{\text {Corresp. } 1}$ \\ ${ }^{1}$ Stream Biofilm and Ecosystem Research Laboratory, École Polytechnique Federale de Lausanne, Lausanne, Switzerland \\ Corresponding Author: Hannes Peter \\ Email address: hannes.peter@epfl.ch
}

Viruses drive microbial diversity, function and evolution and influence important biogeochemical cycles in aquatic ecosystems. Despite their relevance, we currently lack an understanding of their potential impacts on stream biofilm structure and function. This is surprising given the critical role of biofilms for stream ecosystem processes. Currently, the study of viruses in stream biofilms is hindered by the lack of an optimized protocol for their extraction, concentration and purification. Here, we evaluate a range of methods to separate viral particles from stream biofilms, and to concentrate and purify them prior to DNA extraction and metagenome sequencing. Based on epifluorescence microscopy counts of viral-like particles (VLP) and DNA yields, we optimize a protocol including treatment with tetrasodium pyrophosphate and ultra-sonication to disintegrate biofilms, tangential-flow filtration to extract and concentrate VLP, followed by ultracentrifugation in a sucrose density gradient to isolate VLP from the biofilm slurry. Viromes derived from biofilms sampled from three different streams were dominated by Siphoviridae, Myoviridae and Podoviridae and provide first insights into the viral diversity of stream biofilms. Our protocol optimization provides an important step towards a better understanding of the ecological role of viruses in stream biofilms. 


\section{Benchmarking protocols for the metagenomic analysis of stream biofilm viromes}

2 Meriem Bekliz $^{1}$, Jade Brandani ${ }^{1}$, Massimo Bourquin ${ }^{1}$, Tom J Battin ${ }^{1}$, Hannes Peter ${ }^{*}$

3

41 Stream Biofilm and Ecosystem Research Laboratory, Ecole Polytechnique Fédérale de 5 Lausanne, CH-1015 Lausanne, Switzerland

7 Corresponding Author:

8 Hannes Peter

9 Stream Biofilm and Ecosystem Research Laboratory, Ecole Polytechnique Fédérale de

10 Lausanne, CH-1015 Lausanne, Switzerland

11 Email address: Hannes.peter@epfl.ch

13 Abstract

14 Viruses drive microbial diversity, function and evolution and influence important

15 biogeochemical cycles in aquatic ecosystems. Despite their relevance, we currently lack an 16 understanding of their potential impacts on stream biofilm structure and function. This is 17 surprising given the critical role of biofilms for stream ecosystem processes. Currently, the study 18 of viruses in stream biofilms is hindered by the lack of an optimized protocol for their extraction, 19 concentration and purification.

20 Here, we evaluate a range of methods to separate viral particles from stream biofilms, and to 21 concentrate and purify them prior to DNA extraction and metagenome sequencing. Based on 22 epifluorescence microscopy counts of viral-like particles (VLP) and DNA yields, we optimize a 23 protocol including treatment with tetrasodium pyrophosphate and ultra-sonication to disintegrate 24 biofilms, tangential-flow filtration to extract and concentrate VLP, followed by 25 ultracentrifugation in a sucrose density gradient to isolate VLP from the biofilm slurry. Viromes 
26 derived from biofilms sampled from three different streams were dominated by Siphoviridae,

27 Myoviridae and Podoviridae and provide first insights into the viral diversity of stream biofilms.

28 Our protocol optimization provides an important step towards a better understanding of the 29 ecological role of viruses in stream biofilms.

30

31

32

33

34

\section{Introduction}

Viruses are the smallest and most abundant biological entities on Earth, typically outnumbering their prokaryotic and eukaryotic hosts by an order of magnitude (Rohwer, 2003, Sime-Ngando, 2014). Viruses are a large reservoir of genetic diversity (Suttle, 2007, Sullivan et al., 2017, Angly et al., 2006, Brum et al., 2015) and occur in all habitats (Paez-Espino et al., 2016), including air (Reche et al., 2018, Rosario et al., 2018), soils (Srinivasiah et al., 2008, Williamson et al., 2017), and deep-sea sediments (Danovaro et al., 2008). The study of viral ecology was pioneered in surface marine systems where viruses that infect bacteria, also known as bacteriophages, are the main source of bacterial mortality (Suttle, 2007, Brum and Sullivan, 2015, Gregory et al., 2019) and impact ecosystem functions such as the cycling of carbon (Breitbart et al., 2018). By lysing their hosts, horizontal gene transfer and metabolic reprogramming, bacteriophages play a pivotal role in structuring microbial communities (Skvortsov et al., 2016, Silva et al., 2017, Rossum et al., 2018, Daly et al., 2019), the flow of energy and matter through food webs (Weitz et al., 2015), the cycling of carbon and nutrients (Dell'Anno et al., 2015, Guidi et al., 2016, Emerson et al., 2018) and the evolution of bacteria (Pal et al., 2007, Rodriguez-Valera et al., 2009, Simmons et al., 2019). Many of these strides

47 have only recently been possible with the advent of molecular tools such as metagenomic sequencing (Rosario and Breitbart, 2011, Brum and Sullivan, 2015, Roux et al., 2016, Roux et al., 2017). In this context, one may differentiate between untargeted approaches, which have 
50 produced a wealth of viral sequences (Paez-Espino et al., 2016) and virome sequencing, in which

51 the viral fraction is purified prior to sequencing, thus ensuring that the sequencing effort is 52 targeted towards viral nucleic acids (Rosario and Breitbart, 2011).

53 Besides the early recognition of the potential of phages to eradicate bacterial biofilms in medical 54 settings (e.g. Chan and Abedon, 2015), little is known about the interactions between biofilms 55 and viruses (Sutherland et al., 2004). While the biofilm matrix may impede the access of viruses 56 to the surface of bacterial cells (Vidakovic et al., 2017), the susceptibility to phage-induced 57 clearance of biofilm has been demonstrated in laboratory experiments (Scanlan and Buckling, 58 2012). Biofilms may also act as a reservoir for virus amplification and viruses may endure 59 periods of unfavorable environmental conditions within the extracellular matrix (Doolittle et al., 60 1996, Briandet et al., 2008). Apart from a few examples (Dann et al., 2016, Silva et al., 2017, 61 Rossum et al., 2018), we lack an understanding of the ecological role of viruses in streams and 62 rivers in general (Peduzzi, 2016) and in stream biofilms in particular (Battin et al., 2016). In 63 streams, biofilms colonize the sedimentary surfaces of the streambed, are biodiversity hotspots 64 comprising members from all three domains of life, and fulfill critical ecosystem processes 65 (Battin et al., 2016). It is reasonable therefore to speculate that viruses also control biodiversity 66 and biomass turnover in stream biofilms with potential consequences for ecosystem functioning 67 and biogeochemical cycling. However, the heterogeneous matrix of stream biofilms has 68 precluded the study of viromes in stream biofilms.

69 In general, viral metagenomics is complicated by the vast diversity of viruses and lack of 70 universal marker genes, the risk of contamination with non-viral DNA and the 71 underrepresentation of viral sequences in databases (Thurber et al., 2009, Hayes et al., 2017).

72 Protocols for sample preparation for viral metagenomics therefore aim at concentrating and 
73 purifying viral-like particles (VLPs) and removing contaminating DNA, while optimizing VLP 74 recovery (e.g. Castro-Mejia et al., 2015). However, it is clear that viruses are lost at every step of

75 these protocols. Large viruses, in the size range typical for bacteria, may be removed by 76 filtration. Some viruses are sensitive to chemicals during purification based on the structure of 77 their capsids, while other viruses may be lost because of differences in buoyant density, critical 78 during purification in density gradient ultracentrifugation (Thurber et al., 2009). It is thus clear 79 that no single protocol to extract all viruses exists and modifying as well as rigorous testing of 80 protocols remains a critical task.

81 The first critical step towards the study of biofilm viruses in streams using virome sequencing 82 requires the effective extraction of viral-like particles (VLPs) from the biofilm matrix. The aim 83 of our study was therefore to optimize a sample-to-sequence pipeline including VLP extraction, 84 concentration and purification towards metagenomic analyses. Our effort was specifically 85 tailored to maximize the yield of viral DNA while minimizing DNA contamination from 86 bacteria, eukaryotic hosts or the environment. To this end, we compared a suite of sequential 87 protocols to generate viral metagenomes from stream biofilms including tangential flow filtration 88 (TFF), polyethylene glycol (PEG) precipitation, physicochemically induced biofilm breakup, and 89 ultracentrifugation followed by nucleic acid extraction. Several of these protocols have been 90 described previously (e.g. Danovaro et al., 2001, Danovaro and Middelboe, 2010, Hurwitz et al., 91 2013, Temmam et al., 2015, Trubl et al., 2016, see Thurber et al., 2009 and Hayes et al., 2017 92 for reviews), but their rigorous testing for virome generation from stream biofilms is lacking at 93 present. We benchmark the efficiency of the different protocols using epifluorescence 94 microscopy counts of VLP and DNA yields, and provide first results of the virome structure 
95 from biofilms in three streams. We provide a step-by-step version of the optimized protocol at

96 protocols.io, which allows for community participation and continuous protocol development.

97

98 Materials \& Methods

99 Sampling

100

101

102

103

104

105

106

107

108

109

110

111

112

113

114

115

117

\section{Biofilm properties}

116 (NovoCyte, ACEA Biosciences). Chlorophyll $a$ content was determined spectrophotometrically 118 (EPS) were extracted from biofilm slurries using $50 \mathrm{mM}$ EDTA and shaking $(1 \mathrm{~h})$ (Battin et al.,

We sampled benthic biofilms from three streams (Switzerland) draining catchments differing in altitude and land use (Table. 1). The Vallon de Nant (VDN) catchment is pristine with vegetation dominated by alpine forests and meadows. The Veveyse (VEV) catchment is characterized by mixed deciduous forests, but also agricultural and urban land use. The Senoge (SNG) catchment is clearly impacted by agricultural land use. During winter, benthic biofilms were randomly collected from stones (5 to $15 \mathrm{~cm}$ in diameter) using sterile brushes and Milli-Q water. Depending on biofilm thickness, we scraped biofilms from cobbles with a total surface area ranging from 1.3 to $2.4 \mathrm{~m}^{2}$ into $10 \mathrm{~L}$ Milli-Q water. Slurries were transported on ice to the laboratory pending further processing.

For bacterial cell counting, samples were fixed with $3.7 \%$ formaldehyde (final concentration) and stored at $4^{\circ} \mathrm{C}$. Bacterial cells were disintegrated from the biofilm matrix using $0.25 \mathrm{mM}$ tetrasodium pyrophosphate in combination with rigorous shaking $(1 \mathrm{~h})$ and sonication (Bransonic Sonifier 450, Branson) on ice (1 min)(Velji and Albright 1993). As previously established (e.g., Besemer et al., 2009), cells were stained using Syto13 and counted on a flow cytometer 17 after over-night extraction in 90\% EtOH (Lorenzen, 1967). Extracellular polymeric substances 
119 2003). Carbohydrates were precipitated in $70 \%$ EtOH $\left(-20^{\circ} \mathrm{C}, 48 \mathrm{~h}\right)$ and measured

120 spectrophotometrically as glucose equivalents (DuBois et al., 1956). Proteins were determined

121 according to Lowry (Lowry et al., 1951).

122

123 Transmission electron microscopy (TEM)

124 A first confirmation of the presence of VLP in biofilms was obtained from TEM. For this, $5 \mu \mathrm{L}$ 125 of unprocessed sample was adsorbed to a glow-discharged carbon-coated copper grid (Canemco 126 \& Marivac, Canada), washed with deionized water, and stained with $5 \mu \mathrm{L}$ of $2 \%$ uranyl acetate. 127 TEM observations were made on an F20 electron microscope (ThermoFisher, Hillsboro, USA) 128 operated at $200 \mathrm{kV}$ and equipped with a 4098 x 4098 pixel camera (CETA, ThermoFisher). 129 Magnification ranged from 10000 to $29000 \times$, using a defocus range of -1.5 to $-2.5 \mu \mathrm{m}$. 130

\section{Protocols for the extraction of VLP}

132 In order to establish an optimized stream biofilm sample-to-sequence pipeline, we explored a 133 variety of protocols for the concentration, extraction and purification of VLP (Fig. 1). The 134 pipeline consists of three main parts: concentration, extraction and purification. The 135 concentration step is required to obtain sufficient genetic material for nucleic acid extraction. 136 Extraction aims to liberate VLP from the biofilm matrix, while purification aims to reduce the 137 amount of contaminant nucleic acids and cellular debris. The order - first volume reduction, then 138 chemical detachment - was chosen because chemicals used for extraction of VLP may damage 139 tangential flow filters. We tested all possible combinations of protocols to identify the most 140 promising laboratory pipeline for the preparation of viral metagenomes. 
141 First, we homogenized the biofilm slurries by manual shaking and split samples into aliquots (1

$142 \mathrm{~L})$. Aliquots were centrifuged at $100 \times \mathrm{g}(15 \mathrm{~min})(5810 \mathrm{R}$, Eppendorf, Hamburg, Germany) to 143 remove large sediment particles and organisms contained within the biofilm slurry. We 144 recovered the supernatant for downstream analyses.

Concentration

147 We evaluated tangential flow filtration (TFF) and polyethylene glycol (PEG) precipitation to 148 concentrate the viral size fraction. A medium-scale TFF system equipped with a $100 \mathrm{kDa}$ 149 tangential flow filter (GE Healthcare, USA) was used (Thurber et al., 2009). Viruses were 150 collected in the retentate, whereas water and particles smaller than the pore size were discarded. 151 For each aliquot, the initial volume was reduced to less than $50 \mathrm{~mL}$.

152 PEG precipitation was performed as described previously (Bibby and Peccia, 2013). Aliquot 153 biofilm samples were supplemented with 10\% w/v PEG 8000 (Sigma-Aldrich, Germany) and 2.5 $154 \mathrm{M} \mathrm{NaCl}$ (Sigma-Aldrich). The supernatant was then agitated by inverting the tubes three times 155 and stored overnight $\left(4^{\circ} \mathrm{C}\right.$ ), followed by centrifugation for 30 minutes at $9432 \times \mathrm{g}$ at $4^{\circ} \mathrm{C}$ (Sorvall 156 RC-5C centrifuge, HS-4 rotor, ThermoFisher). Supernatants were carefully removed and the 157 resulting pellets were eluted with $50 \mathrm{~mL}$ sterile $\mathrm{H}_{2} \mathrm{O}$.

\section{Extraction}

160 We tested three different physicochemical treatments (chloroform, tetrasodium pyrophosphate in 161 combination with sonication and dithiothreitol (DTT)) to dislodge viruses from the biofilm 162 matrix. To one subset of the samples, we added 0.2 volumes of chloroform and mixed by 163 inversion. Then, these samples were incubated at $4{ }^{\circ} \mathrm{C}$ for 30 minutes, vortexed every 5 minutes, 
164 and centrifuged at $3234 \times \mathrm{g}$ for 15 minutes at $4^{\circ} \mathrm{C}(5810 \mathrm{R}$, Eppendorf, Germany) to recover the

165 supernatant (Marhaver et al., 2008, Thurber et al., 2008).

166 Following the recommendation of Danovaro and Middelboe (2010), we used sonication in 167 combination with tetrasodium phosphate to separate viruses from biofilms. For this, we added 5 $168 \mathrm{mM}$ of tetrasodium pyrophosphate (final concentration) to another subset of concentrated biofilm 169 samples and incubated them in the dark (15 minutes). Then, all samples were sonicated 170 (frequency: $40 \mathrm{KHz}$; Bransonic Sonifier 450, Branson) three times for 1 minute with 30-second 171 intervals during which the samples were manually shaken. To prevent heating, samples were put 172 on ice during sonication. Finally, one subset of the samples were treated with $6.5 \mathrm{mM}$ DTT and 173 incubated for 1 hour at $37^{\circ} \mathrm{C}$ (Lim et al., 2014). At the end of the incubation period, samples 174 were chilled on ice. Biofilm samples without chemical treatment served as controls. After each 175 treatment, these samples were first centrifuged $\left(4^{\circ} \mathrm{C}\right)$ at $3234 \times \mathrm{g}$ for 15 minutes $(5810 \mathrm{R}$, 176 Eppendorf) and the supernatant was sequentially filtered through $0.8 \mu \mathrm{m}$ and $0.45 \mu \mathrm{m}$ filters 177 (Whatman, GE Healthcare, USA) to remove debris and cells.

178

179 Purification

180 To eliminate contaminating eukaryotic, prokaryotic and extracellular nucleic acids, DNase I at a 181 final concentration of $2.5 \mathrm{U} / \mu \mathrm{L}$ (Life Technologies, Germany) and Tris buffer (100 mM Tris $\mathrm{pH}$ $1827.5,5 \mathrm{mM} \mathrm{CaCl}_{2}$ and $25 \mathrm{mM} \mathrm{MgCl}_{2}$ ) were added to the clarified supernatant and incubated at $18337^{\circ} \mathrm{C}(2 \mathrm{~h})$. To confirm the removal of contaminant DNA, polymerase chain reaction (PCR) 184 targeting the $16 \mathrm{~S}$ rRNA gene was performed using the universal primer pair 341f (5'185 CCTACGGGNGGCWGCAG-3') and 785r (5'-GACTACHVGGGTATCTAAKCC-3')(Thijs et 186 al., 2017). PCR amplification was performed with a Biometra Thermal Cycler using Taq ALLin 
187 polymerase (Axon Lab) according to the manufacturer's instructions with an initial enzyme 188 activation step $\left(95^{\circ} \mathrm{C}\right.$ for 2 minutes) followed by 30 cycles of denaturation $\left(95^{\circ} \mathrm{C}\right.$ for 30 seconds $)$ 189 and hybridization $\left(72^{\circ} \mathrm{C}\right.$ for 30 seconds) and a final elongation $\left(72^{\circ} \mathrm{C}\right.$ for 10 minutes $)$. PCR 190 products were visualized under UV light after migration on an agarose gel stained using GelRed 191 (Biotium, USA). However, we did not assess the potential of PCR inhibition.

192 For final purification of the viral fraction, two protocols of density gradient ultracentrifugation, 193 sucrose and $\mathrm{CsCl}$ density gradients, were assessed. The sucrose density gradient was achieved by $1943 \mathrm{~mL}$ of $0.2-\mu \mathrm{m}$ filtered $66 \%$ sucrose and $7 \mathrm{~mL}$ of $0.2-\mu \mathrm{m}$ filtered $30 \%$ sucrose (Temmam et al., 195 2015). A subset of sample was deposited on top of the sucrose density gradient and centrifuged 196 at $106800 \times \mathrm{g}\left(\right.$ Optima XPN-80 Ultracentrifuge, $32 \mathrm{SWi}$, Beckman Coulter, USA) for $2 \mathrm{~h}$ at $4^{\circ} \mathrm{C}$. 197 The viral fraction was harvested by retrieving $1.5 \mathrm{~mL}$ from the interface between both layers 198 using an $18 \mathrm{G}$ needle. Similarly, subsamples were deposited onto CsCl density gradients 199 composed of layers of $1 \mathrm{~mL}$ of $1.7,1.5,1.35$ and $1.2 \mathrm{~g} / \mathrm{mL} \mathrm{CsCl}$. The purified viral fraction was 200 harvested from just below the interface between the 1.5 and $1.7 \mathrm{~g} / \mathrm{mL} \mathrm{CsCl}$ layers by retrieving $2011.5 \mathrm{~mL}$ using an $18 \mathrm{G}$ needle.

202

203 Enumerating VLPs using epifluorescence microscopy

204 To assess the relative viral extraction efficiency of the various protocols, we counted VLP under 205 an epifluorescence microscopy (AxioImager Z2, Zeiss, Germany) as described by Patel et al. 206 (2007). Because of high background noise owing to the biofilm matrix constituents, samples 207 could only be counted after the purification steps. It should be noted that pyrophosphate 208 concentrations $>10 \mathrm{mM}$ tend to interfere with VLP counting (Danovaro et al., 2001); however, 209 we used $5 \mathrm{mM}$ pyrophosphate during VLP liberation from biofilms. Subsamples were fixed with 
210 formaldehyde, stained with $0.5 \mu \mathrm{L}$ of $1000 \times$ SYBR Gold (Molecular Probes, ThermoScientific, 211 USA) and incubated at room temperature in the dark (30 minutes). After incubation, each sample 212 was filtered onto a $0.02 \mu \mathrm{m}$ pore size membrane filter (Anodisc, Whatman). The filters were 213 mounted on glass slides with a drop of VECTASHIELD antifade mounting medium (Vector 214 Laboratories, Burlingame, USA). VLP were visualized using blue light (488 nm) excitation and 215 green $(512 \mathrm{~nm})$ emission. For each sample, 15 to 20 randomly selected images were acquired 216 with a camera (Axiocam 506 mono, Zeiss) mounted onto the microscope. VLPs were 217 discriminated from bacteria by size $(0.015$ to $0.2 \mu \mathrm{m})$ and enumerated using a custom script in 218 Fiji (Schindelin et al., 2012).

219

220

\section{Nucleic acid extraction}

221 To further assess the efficiency of the tested protocols to obtain viral nucleic acids for 222 metagenome sequencing, we extracted DNA and quantified its concentration. Following 223 Sambrook et al. (1989), 0.1 volume of TE buffer, 0.01 volume of 0.5 M EDTA (pH 8) and 1 224 volume of formamide was added to purified viral samples, and incubated at room temperature 225 (30 minutes). Then, two volumes of cold 100\% EtOH were added and incubated 30 minutes $226\left(4^{\circ} \mathrm{C}\right)$. Samples were centrifuged at $17000 \times \mathrm{g}\left(4^{\circ} \mathrm{C}, 20\right.$ minutes $)$ and pellets washed twice with $22770 \%$ cold EtOH. Pellets were air-dried and resuspended in $567 \mu \mathrm{L}$ of TE buffer $(10 \mathrm{mM}$ Tris and $2281 \mathrm{mM}$ EDTA $(\mathrm{pH} 8.0))$. Thirty $\mu \mathrm{L}$ of warm $10 \%$ SDS and $3 \mu \mathrm{L}$ of proteinase $\mathrm{K}(20 \mathrm{mg} / \mathrm{mL})$ 229 were added and samples were incubated for $1 \mathrm{~h}$ at $37^{\circ} \mathrm{C}$. Next, $100 \mu \mathrm{L}$ of $5 \mathrm{M} \mathrm{NaCl}$ and $80 \mu \mathrm{L}$ of 230 warm hexadecyltrimethylammonium bromide (CTAB) were added and incubated for 10 231 minutes $\left(65^{\circ} \mathrm{C}\right)$ (Doyle and Doyle 1987). DNA was extracted in a series of chloroform, 232 phenol:chloroform:isoamyl alcohol (25:24:1) and chloroform treatments, with centrifugation at 
$23316000 \times \mathrm{g}(10$ minutes $)$ for phase separation. Finally, DNA was precipitated overnight in

234 isopropanol $\left(-20^{\circ} \mathrm{C}\right)$. DNA was concentrated by centrifugation at $16000 \times \mathrm{g}\left(4^{\circ} \mathrm{C}\right)$ for $20 \mathrm{~min}$, 235 and the pellet washed twice with cold $70 \% \mathrm{EtOH}$, air-dried, resuspended in $50 \mu \mathrm{L}$ nuclease-free $236 \mathrm{H}_{2} \mathrm{O}$ and stored $\left(-20^{\circ} \mathrm{C}\right)$. DNA concentration was measured using Qubit and the dsDNA high237 sensitivity kit according to the manufacturer's instructions (Life Technologies, Carlsbad, USA).

\section{Library construction and sequencing}

240 Based on the epifluorescence microscopy counts of VLP and the DNA concentration from 241 purified biofilm samples, we selected samples processed with the best performing pipeline for 242 metagenome sequencing. For sequencing library construction, DNA was sheared with an S2 243 focused ultrasonicator (Covaris, Woburn, USA) to achieve a target size of DNA fragments of 244 around $350 \mathrm{bp}$. We opted for the ACCEL-NGS® 1S PLUS DNA library kit (Swift Biosciences, 245 USA) which allows low quantities of both single- and double-stranded DNA as input (Roux et 246 al., 2016). Library construction and multiplexing was performed following the manufacturer's 247 instructions for DNA inputs $(<1 \mathrm{ng} / \mu \mathrm{L})$ and 20 cycles of indexing PCR. Paired-end sequencing 248 (2 x 300 bp) was performed on a MiSeq System (Illumina, San Diego, USA) at the Lausanne 249 Genomic Technologies Facilities. Raw sequences have been submitted to the European 250 Nucleotide Archive under accession number PRJEB33548.

\section{Bioinformatic analyses}

253 The number of reads and GC content of each sample before and after quality control were 254 calculated using a custom python script. For virome classification, we followed the 255 recommendations to assemble viral contiguous sequences (contigs) according to Roux et al. 
256 (2019). First, BBDuk (v35.79) was used to remove Illumina adapters, filtering and trimming 257 (trimq=12). Next, reads with $>93 \%$ similarity to a human reference genome were discarded 258 (using BBmap). The ACCEL-NGS ${ }^{\circledR}$ 1S Plus library preparation kit includes a low complexity 259 adaptase tail, which was clipped (10 bases) according to the manufacturer's instructions. We 260 then used the error correction capability of Tadpole (v. 37.76) to correct for sequencing errors 261 (mode $=$ correct ecc=t prefilter=2). Prior to assembly, we de-duplicated our datasets using 262 clumpify (v37.76) with parameters set such that identical reads were identified and only one 263 copy was retained (dedupe subs $=0$ ). Finally, we used the SPAdes assembler (v3.13.0, Bankevich 264 et al., 2012) in single-cell (--sc) mode, with error correction disabled (--only-assembler) and 265 kmers set to $21,33,55,77,99,127$ to assemble contigs. We co-assembled the paired-end reads 266 from both sequencing runs for each sample individually. To obtain an overview of the potential 267 contaminant sequences (e.g., human, bacterial and phiX), we uploaded the quality-trimmed and 268 de-replicated reads (forward orientation only) to the web interface of taxonomer (Flygare et al., 269 2016). Taxonomer is an ultrafast taxonomy assigner, which assigns and classifies reads to 270 human, bacterial, viral, phage, fungal, phix, ambiguous (i.e., reads fit to more than one bin) and 271 "unknown" bins. For identification and classification of viral contigs, we used MetaPhinder 272 (v2.1, Jurtz et al., 2016) through the web interface hosted at the Center for Genomic 273 Epidemiology at the Danish Technical University (DTU). We mapped the reads to the contigs 274 using BWA-MEM (http://bio-bwa.sourceforge.net/) using default setting (e.g. a mismatch 275 penalty of 4 and a minimal alignment score of 30) and then counted the number of reads 276 mapping each contig using samtools ( $\mathrm{Li}$ et al. 2009). The average number of reads per contig 277 were adjusted by contig length and normalized by library size to obtain the average percent of 278 reads mapping to contigs. In order to specifically target ssDNA contigs (Trubl et al., 2019), we 
279 matched the contigs to the Viral_rep and Phage_F domains of the PFAM database using 280 hmmsearch (HMMER v3, Eddy, 2011) with cutoff scores $\geq 50$ and e-values $\leq 0.001$.

281

282 Results

\section{Biofilm properties}

284 Bacterial abundance ranged between $4.1 \times 10^{11}$ cells $\mathrm{m}^{-2}$ at the lowest stream (SNG) and $2.3 \times$ $28510^{9}$ cells $\mathrm{m}^{-2}$ at the uppermost stream (VDN; Table 1). This pattern was mirrored by an increase 286 in chlorophyll $a$ content, and the protein and carbohydrate concentrations in EPS that were 287 higher in the lowland than the high-altitude stream (Table 1). Despite these differences in biofilm 288 properties, no differences in extraction efficiency among the different protocols were detected. In 289 fact, the average number of VLPs extracted by the various protocols were strongly correlated 290 among the different samples (pairwise Spearman's $r_{s}$ ranging between 0.94 and 0.98).

291

292 294 295 296 297 298 299 300 301 302

\section{Transmission Electron Microscopy (TEM)}

Direct electron microscopic observations of raw biofilm samples revealed the presence and morphological diversity of virions, including tailed bacteriophages and lemon-shaped viruses, in biofilms from all three streams (Fig. 2). Polyhedral, spherical and filamentous VLPs were also observed, which may include untailed bacteriophages or viruses infecting eukaryotes. Some amorphous structures may also be interpreted as membrane vesicles.

\section{Virome extraction and purification}

In total, we evaluated 16 protocols to concentrate, extract and purify viruses from benthic biofilms from three streams (Fig. 1). Based on the number of VLPs and DNA yields retained at the end of each protocol, we observed significant differences in relative extraction efficiencies 
303 among protocols. Across all samples, average VLP counts and DNA yields were correlated 304 (Spearman's $r_{s}=0.74$ ), suggesting conformity among these two means of evaluation. The 305 combination of TFF for concentration, tetrasodium pyrophosphate and sonication for extraction, 306 and sucrose gradient centrifugation for purification resulted in the highest VLP counts in all three 307 samples (two-way ANOVA, p <0.01; Fig. 3). This pipeline also yielded the highest DNA 308 concentration (Fig. 4). Protocols involving PEG precipitation generally resulted in a lower 309 recovery of VLPs (on average only $13.6 \%$ compared to the best performing pipeline) and DNA 310 yields below detection limit. This may be attributable to the formation of a visible, viscous layer 311 upon addition of PEG to the biofilm samples. The dissociation of VLPs from the biofilm matrix 312 was most effective using tetrasodium pyrophosphate and sonication (two-way ANOVA, $\mathrm{p}<0.01$ ). 313 Protocols based on TFF and using DTT or chloroform extracted on average $25.0 \%$ and $33.2 \%$ 314 less VLPs than protocols using TFF followed by tetrasodium pyrophosphate treatment and 315 sonication (Fig. 3). Samples without any physicochemical treatment to extract VLP from 316 biofilms yielded on average 54.8\% less VLPs than the tetrasodium pyrophosphate and sonication 317 treatment. To further purify viruses, two discontinuous gradient formulations with sucrose and $318 \mathrm{CsCl}$ were tested. On average, 1.9 times more VLPs were retained by ultracentrifugation using 319 the sucrose gradient than using the $\mathrm{CsCl}$ gradient in samples concentrated using TFF and treated 320 with tetrasodium pyrophosphate and sonication (paired-T-Test, $\mathrm{p}<0.01$ ). This is also reflected in 321 DNA yields, which reached $1.22 \mathrm{ng} \mu \mathrm{L}^{-1}$ in $\mathrm{VDN}, 1.31 \mathrm{ng} \mu \mathrm{L}^{-1}$ in $\mathrm{VEV}$ and $18.7 \mathrm{ng} \mu \mathrm{L}^{-1}$ in $\mathrm{SNG}$ 322 using TFF, pyrophosphate and sonication followed by sucrose gradient centrifugation. DNA 323 yields were on average 3 times higher using ultracentrifugation in the sucrose compared to the $324 \mathrm{CsCl}$ gradient (paired T-Test, $\mathrm{p}=0.03$ ) and on average 1.5, 1.7 and 1.9 times higher using 
325 tetrasodium pyrophosphate and sonication compared to DTT, no physico-chemical detachment 326 and chloroform, respectively.

327 Given that stream biofilms contain abundant prokaryotic, eukaryotic and extracellular DNA, it is 328 crucial to verify the absence of DNA potentially contaminating the samples. Negative PCR 329 results from samples treated with DNase I confirmed the absence of DNA contamination from 330 prokaryotic cells.

331

\section{Stream biofilm viromes}

333 From the two sequencing runs we obtained 24388096, 22459218 and 23804190 paired-end reads

334 from SNG, VEV and VDN, respectively (Table 2). After quality control, error correction and 335 deduplication, on average $97.5 \%$ of the reads remained. Initial screening using taxonomer 336 showed that human contaminant reads accounted for 0.13 to $0.25 \%$ of the reads, while bacterial 337 contaminant reads accounted for 1.47 to $8.11 \%$ of the reads.

338 We obtained 3698, 11323 and 13591 contigs from de-novo assembly of quality-controlled and 339 deduplicated reads from SNG, VEV and VDN, respectively. The largest contigs were 9493, 34046665 and 54492 bp in SNG, VEV and VDN, respectively. Hmmsearch against the PFAM 341 databases did not yield ssDNA contigs in the three viromes. Between 726 and 2613 contigs were

342 classified as of viral origin in the three viromes (Fig. 5). In all samples, the majority of contigs 343 were identified as not further classified Siphoviridae (28.3 - 53.3\%), followed by Myoviridae 344 (9.6 - 18.0\%) and Podoviridae (4.7 - 5.2\%). Contigs classified as T4virus, Cp220virus, Kayvirus 345 and P12024virus were common in all three biofilm viromes. However, contigs classified as 346 Twortvirus, Phicbkvirus, Coopervirus and L5virus were only detected in viromes obtained from 347 VEV and VDN but not in SNG. Across the three samples, on average 554.6 reads mapped to 
348 contigs classified as Caudovirales, averaging 63.4, 63.8 and $89.1 \%$ bp accounting for contig size

349 in SNG, VEV and VDN, respectively. 153.8 reads mapped to Podoviridae (range $2.2-30.8 \%$ of

$350 \mathrm{bp}$ ) and 115.1 reads mapped to Myoviridae (range $0.4-6.1 \%$ of bp), whereas only 29.4 reads

351 mapped to Siphoviridae (range $1.8-17.7 \%$ of bp). There was substantial variation in the number

352 of reads mapped to contigs in the different samples. For instance, more reads mapped on average

353 to unclassified bacterial viruses and Myoviridae in SNG (311.1 and 339.7 reads accounting for

3549.3 and $6.1 \%$ of bp) than in VDN (2.6 and 2.8 reads accounting for 0.6 and $0.8 \%$ bp) or VEV

355 (36.7 and 2.8 reads accounting for 1.5 and $0.4 \% \mathrm{bp}$ ).

356

\section{Discussion}

358 The advent of metagenomic tools has revolutionized the study of the role of viruses in numerous 359

ecosystems (Suttle, 2007, Rosario and Breitbart, 2011, Brum and Sullivan, 2015, Trubl et al., 2019). For biofilms in general, and particularly for biofilms in streams and rivers, however, an optimized protocol for viral metagenomics has been missing. Here, we establish an optimized sample-to-sequence pipeline for the concentration and purification of viruses from stream biofilms. This protocol is publicly available at https://www.protocols.io/view/extraction-andpurification-of-viruses-from-stream-32qgqdw. We used two metrics, the number of VLP retained and the amount of DNA extracted from the samples to evaluate the performance of the different combinations of protocols (Fig. 3, Fig. 4). This approach allowed us to obtain a relative comparison among the tested protocols. However, it does not permit the quantification of extraction efficiencies since it was not possible to enumerate VLPs without prior extraction and purification.

The best performing sample-to-sequence pipeline involves TFF for sample concentration, pyrophosphate and sonication for the detachment of viruses from the biofilm matrix and DNase I 
372 treatment followed by sucrose gradient ultracentrifugation for purification. This is similar to

373 protocols for other complex samples, such as soils (Trubl et al., 2016) or marine and freshwater 374 sediments (Danovaro and Middelboe, 2010). The suggested combination of protocols was 375 consistently the best performing pipeline for biofilms obtained from three streams differing in 376 trophic state and with different biofilm properties (Table 1). However, depending on biofilm 377 biomass, sampling efforts should be tailored towards obtaining sufficient nucleic material for 378 virome metagenomic sequencing. For instance, in the oligotrophic mountain stream, sampling 379 biofilms from $0.5 \mathrm{~m}^{2}$ (approximately $10-12$ pebbles of 5-10 $\mathrm{cm}$ diameter) and using $1 \mathrm{~L}$ of Milli380 Q water suffices to generate viromes using the optimized protocols and an appropriate library 381 preparation strategy.

382 The viromes obtained using the best-performing protocol were dominated by reads of viral or 383 unknown origin (presumably reflecting the lack of viral sequences in public databases), and 384 contaminant sequences (i.e., of bacterial or human origin) contributed only marginally to the 385 viromes. Following an optimized assembly strategy (Roux et al., 2019), the reads assembled into 386 a large number of contigs, however, of small average contig size. Still many of the contigs were 387 classified as of viral origin. Viral community composition was remarkably similar across the 388 three different stream biofilms, with several contigs classified as T4virus, Cp220virus, Kayvirus 389 and P12024virus found in all samples. Despite the use of the ACCEL-NGS® 1S PLUS DNA kit 390 (Roux et al., 2016), ssDNA viruses, which account for $<5 \%$ of DNA viral communities in other 391 freshwater, marine and soil ecosystems (Roux et al., 2016, Trubl et al., 2019) could not be 392 detected in the viromes from stream biofilms. This may be related to the choice of the density 393 gradient harvested during the final purification step (Kauffman et al., 2018). Due to the low 394 buoyant density of ssDNA viruses (Thurber et al., 2009), additionally sampling from, for 
395 instance, a $1.3 \mathrm{~g} / \mathrm{mL} \mathrm{CsCl}$ density layer (Trubl et al., 2019) may be advisable to specifically

396 target ssDNA viruses. Strikingly, the virome obtained from the most eutrophic stream (SNG)

397 resulted in the lowest number of viral contigs and lacked contigs classified as Twortvirus,

398 Phicbkvirus, Coopervirus and L5virus. However, given the low number of samples, we caution

399 against concluding an anthropogenic effect on stream biofilm viral communities.

400 A range of chemical properties may explain the relative differences in virus extraction efficiency

401 from stream biofilms. PEG precipitation generally failed to concentrate viruses from biofilm

402 slurries, potentially due to the formation of a viscous layer that impaired PEG removal.

403 Previously described methods for isolating viruses involve chloroform (Marhaver et al., 2008,

404 Thurber et al., 2008, Hewson et al., 2012); however, chloroform may denature the lipid

405 envelopes surrounding viral capsids, internal lipid membranes and nucleo-cytoplasmic large

406 DNA viruses (NCLDV), including Phycodnaviridae, which predominantly infect freshwater and

407 marine algae, may be sensitive to chloroform treatment (Feldman and Wang, 1961). Similarly,

408 DTT is a reducing agent, which breaks disulfide bonds in proteins. This may explain to the

409 reduced recovery of VLPs from samples treated with PEG, chloroform or DTT.

410 Extracellular DNA is a common component of the biofilm matrix (Flemming and Wingender,

411 2010), which together with DNA from damaged eukaryotic and prokaryotic cells needs to be

412 removed prior to virome sequencing. We propose a DNase I treatment as an efficient way to

413 digest extracellular DNA from biofilms, followed by sucrose density gradient ultracentrifugation

414 for further purification. However, DNase I will not degrade ssDNA or RNA and recent studies

415 used nuclease cocktails including DNases, RNases and Benzoases (Temmam et al., 2015,

416 Rosario et al., 2018,) to eliminate various contaminant nucleic acids. The treatment order is

417 important because otherwise DNA from viral particles damaged during ultracentrifugation may 
418 be digested by the DNase digestion. Compared to ultracentrifugation in a $\mathrm{CsCl}$ gradient, sucrose 419 gradient ultracentrifugation probably maximized the purification of a wider range of viruses

420 because of the larger gradient of densities recovered with this method. Moreover, $\mathrm{CsCl}$ density 421 gradient separation may exclude viral particles as that may be too buoyant (Thurber et al., 2009, 422 Kauffman et al., 2018), or degrade the structure of enveloped viruses (Lawrence and Steward, 423 2010) and therefore reduce their recovery. Critical steps of virome preparation concerns nucleic 424 acid extraction and library preparation. We chose a derivation of a standard extraction protocol, 425 which allows the extraction of both ssDNA and dsDNA viruses (Sambrook et al., 1989). 426 Optimization of DNA extraction protocols, such as done for soil viromes (Trubl et al., 2018), 427 may be necessary for biofilms sampled from environments with high humic acid concentrations 428 such as in boreal streams or streams draining wetlands, potentially causing inhibition during 429 library preparation.

430 Finally, there is a plethora of tools available for the bioinformatic analysis of viromes (e.g. those 431 implemented in iVirus (Bolduc et al., 2017) and available through powerful computational 432 infrastructures such as CyVerse (www.cyverse.org) or KBase (www.kbase.us). Here, we opted 433 for contig assembly, classification and read mapping to assess the capability of the laboratory 434 procedures to generate diverse viromes from stream biofilm. Clearly, the choice of bioinformatic 435 analyses depends on the specific questions regarding the composition and role of viruses in 436 stream biofilms.

438 Conclusions

439 In conclusion, we provide a first protocol for the generation of viromes from stream biofilms.

440 The sample-to-sequence pipeline generates diverse viromes, however the purification scheme 441 may select against viruses with different buoyant densities, such as ssDNA viruses or viruses 
442 containing lipids. Similarly, filtration may discriminate against large or filamentous viruses and

443 some viruses may be sensitive to chemicals used during biofilm breakup. However, this is a first

444 step towards a better understanding of the roles viruses may play in stream ecology. By

445 providing a step-by-step protocol on protocols.io, we hope to further stimulate research on phage

446 diversity in stream biofilms.

447

448

449

450

451

452

453

454

455

456

457

458

459

460

461

462

463

464

465

466

467

468

469

470

471

472

473

474

475

476

477

478

479

480

481

\section{Acknowledgements}

We acknowledge the help of Davide Demurtas for TEM imaging at EPFL (CIME).

\section{References}

Angly FE, Felts B, Breitbart M, Salamon P, Edwards RA, Carlson C, Chan AM, Haynes M, Kelley S, Liu H, Mahaffy JM, Mueller JE, Nulton J, Olson R, Parsons R, Rayhawk S, Suttle CA, and Rohwer F. 2006. The marine viromes of four oceanic regions. PLoS Biol 4:e368. 10.1371/journal.pbio.0040368

Bankevich A, Nurk S, Antipov D, Gurevich AA, Dvorkin M, Kulikov AS, Lesin VM, Nikolenko SI, Pham S, Prjibelski AD, Pyshkin AV, Sirotkin AV, Vyahhi N, Tesler G, Alekseyev MA, and Pevzner PA. 2012. SPAdes: a new genome assembly algorithm and its applications to single-cell sequencing. J Comput Biol 19:455-477. 10.1089/cmb.2012.0021

Battin TJ, Besemer K, Bengtsson MM, Romani AM, and Packmann AI. 2016. The ecology and biogeochemistry of stream biofilms. Nat Rev Microbiol 14:251-263. 10.1038/nrmicro.2016.15

Battin TJ, Kaplan LA, Newbold JD, Cheng X, and Hansen C. 2003. Effects of current velocity on the nascent architecture of stream microbial biofilms. Appl Environ Microbiol 69:5443-5452.

Besemer K, Hödl I, Singer G, and Battin TJ. 2009. Architectural differentiation reflects bacterial community structure in stream biofilms. ISME J 3:1318. 10.1038/ismej.2009.73

Bibby K, and Peccia J. 2013. Identification of viral pathogen diversity in sewage sludge by metagenome analysis. Environ Sci Technol 47:1945-1951. 10.1021/es305181x

Bolduc B, Youens-Clark K, Roux S, Hurwitz BL, and Sullivan MB. 2017. iVirus: facilitating new insights in viral ecology with software and community data sets imbedded in a cyberinfrastructure. ISME J 11:7-14. 10.1038/ismej.2016.89

Breitbart M, Bonnain C, Malki K, and Sawaya NA. 2018. Phage puppet masters of the marine microbial realm. Nature Microbiology 3:754-766. 10.1038/s41564-018-0166-y

Briandet R, Lacroix-Gueu P, Renault M, Lecart S, Meylheuc T, Bidnenko E, Steenkeste K, Bellon-Fontaine MN, and Fontaine-Aupart MP. 2008. Fluorescence correlation spectroscopy to study diffusion and reaction of bacteriophages inside biofilms. Appl Environ Microbiol 74:2135-2143. 10.1128/aem.02304-07

Brum JR, Ignacio-Espinoza JC, Roux S, Doulcier G, Acinas SG, Alberti A, Chaffron S, Cruaud C, de Vargas C, Gasol JM, Gorsky G, Gregory AC, Guidi L, Hingamp P, Iudicone D, Not 
482

483

484

485

486

487

488

489

490

491

492

493

494

495

496

497

498

499

500

501

502

503

504

505

506

507

508

509

510

511

512

513

514

515

516

517

518

519

520

521

522

523

524

525

526

527

F, Ogata H, Pesant S, Poulos BT, Schwenck SM, Speich S, Dimier C, Kandels-Lewis S, Picheral M, Searson S, Bork P, Bowler C, Sunagawa S, Wincker P, Karsenti E, and Sullivan MB. 2015. Patterns and ecological drivers of ocean viral communities. Science 348:1261498. 10.1126/science. 1261498

Brum JR, and Sullivan MB. 2015. Rising to the challenge: accelerated pace of discovery transforms marine virology. Nature Reviews Microbiology 13:147. 10.1038/nrmicro3404

Castro-Mejia JL, Muhammed MK, Kot W, Neve H, Franz CM, Hansen LH, Vogensen FK, and Nielsen DS. 2015. Optimizing protocols for extraction of bacteriophages prior to metagenomic analyses of phage communities in the human gut. Microbiome 3:64. 10.1186/s40168-015-0131-4

Chan BK, and Abedon ST. 2015. Bacteriophages and their enzymes in biofilm control. Curr Pharm Des 21:85-99.

Daly RA, Roux S, Borton MA, Morgan DM, Johnston MD, Booker AE, Hoyt DW, Meulia T, Wolfe RA, Hanson AJ, Mouser PJ, Moore JD, Wunch K, Sullivan MB, Wrighton KC, and Wilkins MJ. 2019. Viruses control dominant bacteria colonizing the terrestrial deep biosphere after hydraulic fracturing. Nat Microbiol 4:352-361. 10.1038/s41564-0180312-6

Dann LM, Paterson JS, Newton K, Oliver R, and Mitchell JG. 2016. Distributions of Virus-Like Particles and Prokaryotes within Microenvironments. PLOS ONE 11:e0146984. 10.1371/journal.pone.0146984

Danovaro R, Dell'anno A, Trucco A, Serresi M, and Vanucci S. 2001. Determination of virus abundance in marine sediments. Applied and Environmental Microbiology 67:1384-1387.

Danovaro R, Dell'Anno A, Corinaldesi C, Magagnini M, Noble R, Tamburini C, and Weinbauer M. 2008. Major viral impact on the functioning of benthic deep-sea ecosystems. Nature 454:1084. 10.1038/nature07268

Danovaro R, and Middelboe M. 2010. Separation of free virus particles from sediments in aquatic systems. In: Wilhelm SW, Weinbauer MG, and Suttle CA, eds. Manual of Aquatic Viral Ecology Waco, TX: American Society of Limnology and Oceanography.

Dell'Anno A, Corinaldesi C, and Danovaro R. 2015. Virus decomposition provides an important contribution to benthic deep-sea ecosystem functioning. Proc Natl Acad Sci US A 112:E2014-2019. 10.1073/pnas.1422234112

Doolittle MM, Cooney JJ, and Caldwell DE. 1996. Tracing the interaction of bacteriophage with bacterial biofilms using fluorescent and chromogenic probes. $J$ Ind Microbiol 16:331341.

Doyle JJ, and Doyle JL. 1987. A rapid DNA isolation procedure for small quantities of fresh leaf tissue. Phytochemical Bulletin 19:11-15.

DuBois M, Gilles KA, Hamilton JK, Rebers PA, and Smith F. 1956. Colorimetric Method for Determination of Sugars and Related Substances. Analytical Chemistry 28:350-356. $10.1021 / \mathrm{ac} 60111 \mathrm{a} 017$

Eddy SR. 2011. Accelerated Profile HMM Searches. PLoS Comput Biol 7:e1002195. 10.1371/journal.pcbi.1002195

Emerson JB, Roux S, Brum JR, Bolduc B, Woodcroft BJ, Jang HB, Singleton CM, Solden LM, Naas AE, Boyd JA, Hodgkins SB, Wilson RM, Trubl G, Li C, Frolking S, Pope PB, Wrighton KC, Crill PM, Chanton JP, Saleska SR, Tyson GW, Rich VI, and Sullivan MB. 2018. Host-linked soil viral ecology along a permafrost thaw gradient. Nature Microbiology 3:870-880. 10.1038/s41564-018-0190-y

PeerJ reviewing PDF | (2019:07:39489:2:0:NEW 31 Oct 2019) 
528

529

530

531

532

533

534

535

536

537

538

539

540

541

542

543

544

545

546

547

548

549

550

551

552

553

554

555

556

557

558

559

560

561

562

563

564

565

566

567

568

569

570

571

Feldman HA, and Wang SS. 1961. Sensitivity of Various Viruses to Chloroform. Proceedings of the Society for Experimental Biology and Medicine 106:736-738. 10.3181/00379727106-26459

Flemming HC, and Wingender J. 2010. The biofilm matrix. Nat Rev Microbiol 8:623-633. $10.1038 /$ nrmicro2415

Flygare S, Simmon K, Miller C, Qiao Y, Kennedy B, Di Sera T, Graf EH, Tardif KD, Kapusta A, Rynearson S, Stockmann C, Queen K, Tong S, Voelkerding KV, Blaschke A, Byington CL, Jain S, Pavia A, Ampofo K, Eilbeck K, Marth G, Yandell M, and Schlaberg R. 2016. Taxonomer: an interactive metagenomics analysis portal for universal pathogen detection and host mRNA expression profiling. Genome Biol 17:111. 10.1186/s13059-016-0969-1

Gregory AC, Zayed AA, Conceicao-Neto N, Temperton B, Bolduc B, Alberti A, Ardyna M, Arkhipova K, Carmichael M, Cruaud C, Dimier C, Dominguez-Huerta G, Ferland J, Kandels S, Liu Y, Marec C, Pesant S, Picheral M, Pisarev S, Poulain J, Tremblay JE, Vik D, Babin M, Bowler C, Culley AI, de Vargas C, Dutilh BE, Iudicone D, Karp-Boss L, Roux S, Sunagawa S, Wincker P, and Sullivan MB. 2019. Marine DNA Viral Macro- and Microdiversity from Pole to Pole. Cell 177:1109-1123 e1114. 10.1016/j.cell.2019.03.040

Guidi L, Chaffron S, Bittner L, Eveillard D, Larhlimi A, Roux S, Darzi Y, Audic S, Berline L, Brum J, Coelho LP, Espinoza JCI, Malviya S, Sunagawa S, Dimier C, Kandels-Lewis S, Picheral M, Poulain J, Searson S, Stemmann L, Not F, Hingamp P, Speich S, Follows M, Karp-Boss L, Boss E, Ogata H, Pesant S, Weissenbach J, Wincker P, Acinas SG, Bork P, de Vargas C, Iudicone D, Sullivan MB, Raes J, Karsenti E, Bowler C, and Gorsky G. 2016. Plankton networks driving carbon export in the oligotrophic ocean. Nature 532:465-470. 10.1038/nature16942

Hayes S, Mahony J, Nauta A, and van Sinderen D. 2017. Metagenomic Approaches to Assess Bacteriophages in Various Environmental Niches. Viruses 9. 10.3390/v9060127

Hewson I, Brown JM, Burge CA, Couch CS, LaBarre BA, Mouchka ME, Naito M, and Harvell CD. 2012. Description of viral assemblages associated with the Gorgonia ventalina holobiont. Coral Reefs 31:487-491. 10.1007/s00338-011-0864-x

Hurwitz BL, Deng L, Poulos BT, and Sullivan MB. 2013. Evaluation of methods to concentrate and purify ocean virus communities through comparative, replicated metagenomics. Environ Microbiol 15:1428-1440. 10.1111/j.1462-2920.2012.02836.x

Jurtz VI, Villarroel J, Lund O, Voldby Larsen M, and Nielsen M. 2016. MetaPhinder-Identifying Bacteriophage Sequences in Metagenomic Data Sets. PLOS ONE 11:e0163111. 10.1371/journal.pone.0163111

Kauffman KM, Hussain FA, Yang J, Arevalo P, Brown JM, Chang WK, VanInsberghe D, Elsherbini J, Sharma RS, Cutler MB, Kelly L, and Polz MF. 2018. A major lineage of non-tailed dsDNA viruses as unrecognized killers of marine bacteria. Nature 554:118. 10.1038 /nature25474

Lawrence JE, and Steward GF. 2010. Purification of viruses by centrifugation. In: Wilhelm SW, Weinbauer MG, and Suttle CA, eds. Manual of Aquatic Viral Ecology: ASLO, 166-181.

Li H, Handsaker B, Wysoker A, Fennell T, Ruan J, Homer N, Marth G, Abecasis G, and Durbin R. 2009. The Sequence Alignment/Map format and SAMtools. Bioinformatics 25:20782079. 10.1093/bioinformatics/btp352

PeerJ reviewing PDF | (2019:07:39489:2:0:NEW 31 Oct 2019) 
572

573

574

575

576

577

578

579

580

581

582

583

584

585

586

587

588

589

590

591

592

593

594

595

596

597

598

599

600

601

602

603

604

605

606

607

608

609

610

611

612

613

614

615

616

Lim YW, Haynes M, Furlan M, Robertson CE, Harris JK, and Rohwer F. 2014. Purifying the Impure: Sequencing Metagenomes and Metatranscriptomes from Complex Animalassociated Samples. JoVE:e52117. doi:10.3791/52117

Lorenzen CJ. 1967. Determination of chlorophyll and pheo-pigments: spectrophotometric equations. Limnology and Oceanography 12:343-346. 10.4319/lo.1967.12.2.0343

Lowry OH, Rosebrough NJ, Farr AL, and Randall RJ. 1951. Protein measurement with the Folin phenol reagent. $J$ Biol Chem 193:265-275.

Marhaver KL, Edwards RA, and Rohwer F. 2008. Viral communities associated with healthy and bleaching corals. Environmental microbiology 10:2277-2286. 10.1111/j.14622920.2008.01652.x

Paez-Espino D, Eloe-Fadrosh EA, Pavlopoulos GA, Thomas AD, Huntemann M, Mikhailova N, Rubin E, Ivanova NN, and Kyrpides NC. 2016. Uncovering Earth's virome. Nature 536:425-430. 10.1038/nature19094

Pal C, Macia MD, Oliver A, Schachar I, and Buckling A. 2007. Coevolution with viruses drives the evolution of bacterial mutation rates. Nature 450:1079-1081. 10.1038/nature06350

Patel A, Noble RT, Steele JA, Schwalbach MS, Hewson I, and Fuhrman JA. 2007. Virus and prokaryote enumeration from planktonic aquatic environments by epifluorescence microscopy with SYBR Green I. Nat Protoc 2:269-276. 10.1038/nprot.2007.6

Peduzzi P. 2016. Virus ecology of fluvial systems: a blank spot on the map? Biol Rev Camb Philos Soc 91:937-949. 10.1111/brv.12202

Reche I, D'Orta G, Mladenov N, Winget DM, and Suttle CA. 2018. Deposition rates of viruses and bacteria above the atmospheric boundary layer. ISME J 12:1154-1162. 10.1038/s41396-017-0042-4

Rodriguez-Valera F, Martin-Cuadrado A-B, Rodriguez-Brito B, Pasic L, Thingstad TF, Rohwer F, and Mira A. 2009. Explaining microbial population genomics through phage predation. Nature Reviews Microbiology 7:828-836.

Rohwer F. 2003. Global Phage Diversity. Cell 113:141. https://doi.org/10.1016/S00928674(03)00276-9

Rosario K, and Breitbart M. 2011. Exploring the viral world through metagenomics. Curr Opin Virol 1:289-297. 10.1016/j.coviro.2011.06.004

Rosario K, Fierer N, Miller S, Luongo J, and Breitbart M. 2018. Diversity of DNA and RNA Viruses in Indoor Air As Assessed via Metagenomic Sequencing. Environ Sci Technol 52:1014-1027. 10.1021/acs.est.7b04203

Rossum TV, Uyaguari-Diaz MI, Vlok M, Peabody MA, Tian A, Cronin KI, Chan M, Croxen MA, Hsiao WWL, Isaac-Renton J, Tang PKC, Prystajecky NA, Suttle CA, and Brinkman FSL. 2018. Spatiotemporal dynamics of river viruses, bacteria and microeukaryotes. bioRxiv:259861. 10.1101/259861

Roux S, Emerson JB, Eloe-Fadrosh EA, and Sullivan MB. 2017. Benchmarking viromics: an in silico evaluation of metagenome-enabled estimates of viral community composition and diversity. PeerJ 5:e3817. 10.7717/peerj.3817

Roux S, Solonenko NE, Dang VT, Poulos BT, Schwenck SM, Goldsmith DB, Coleman ML, Breitbart M, and Sullivan MB. 2016. Towards quantitative viromics for both doublestranded and single-stranded DNA viruses. PeerJ 4:e2777. 10.7717/peerj.2777

Roux S, Trubl G, Goudeau D, Nath N, Couradeau E, Ahlgren NA, Zhan Y, Marsan D, Chen F, Fuhrman JA, Northen TR, Sullivan MB, Rich VI, Malmstrom RR, and Eloe-Fadrosh EA.

PeerJ reviewing PDF | (2019:07:39489:2:0:NEW 31 Oct 2019) 
617

618

619

620

621

622

623

624

625

626

627

628

629

630

631

632

633

634

635

636

637

638

639

640

641

642

643

644

645

646

647

648

649

650

651

652

653

654

655

656

657

658

659

660

661

2019. Optimizing de novo genome assembly from PCR-amplified metagenomes. PeerJ 7:e6902. 10.7717/peerj.6902

Sambrook J, Fritsch EF, and Maniatis T. 1989. Molecular Cloning: a laboratory manual. New York: Cold Spring Harbor Laboratory Press.

Scanlan PD, and Buckling A. 2012. Co-evolution with lytic phage selects for the mucoid phenotype of Pseudomonas fluorescens SBW25. ISME J 6:1148-1158.

Schindelin J, Arganda-Carreras I, Frise E, Kaynig V, Longair M, Pietzsch T, Preibisch S, Rueden C, Saalfeld S, Schmid B, Tinevez JY, White DJ, Hartenstein V, Eliceiri K, Tomancak P, and Cardona A. 2012. Fiji: an open-source platform for biological-image analysis. Nat Methods 9:676-682. 10.1038/nmeth.2019

Silva BSO, Coutinho FH, Gregoracci GB, Leomil L, de Oliveira LS, Froes A, Tschoeke D, Soares AC, Cabral AS, Ward ND, Richey JE, Krusche AV, Yager PL, de Rezende CE, Thompson CC, and Thompson FL. 2017. Virioplankton Assemblage Structure in the Lower River and Ocean Continuum of the Amazon. mSphere 2. 10.1128/mSphere.0036617

Sime-Ngando T. 2014. Environmental bacteriophages: viruses of microbes in aquatic ecosystems. Frontiers in microbiology 5:355-355. 10.3389/fmicb.2014.00355

Simmons M, Bond MC, Drescher K, Bucci V, and Nadell CD. 2019. Evolutionary dynamics of phage resistance in bacterial biofilms. bioRxiv:552265. 10.1101/552265

Skvortsov T, de Leeuwe C, Quinn JP, McGrath JW, Allen CC, McElarney Y, Watson C, Arkhipova K, Lavigne R, and Kulakov LA. 2016. Metagenomic Characterisation of the Viral Community of Lough Neagh, the Largest Freshwater Lake in Ireland. PLOS ONE 11:e0150361. 10.1371/journal.pone.0150361

Srinivasiah S, Bhavsar J, Thapar K, Liles M, Schoenfeld T, and Wommack KE. 2008. Phages across the biosphere: contrasts of viruses in soil and aquatic environments. Research in Microbiology 159:349-357. https://doi.org/10.1016/j.resmic.2008.04.010

Sullivan MB, Weitz JS, and Wilhelm S. 2017. Viral ecology comes of age. Environmental Microbiology Reports 9:33-35. 10.1111/1758-2229.12504

Sutherland IW, Hughes KA, Skillman LC, and Tait K. 2004. The interaction of phage and biofilms. FEMS Microbiol Lett 232:1-6.

Suttle CA. 2007. Marine viruses--major players in the global ecosystem. Nat Rev Microbiol 5:801-812. 10.1038/nrmicro1750

Temmam S, Monteil-Bouchard S, Robert C, Pascalis H, Michelle C, Jardot P, Charrel R, Raoult D, and Desnues C. 2015. Host-Associated Metagenomics: A Guide to Generating Infectious RNA Viromes. PLOS ONE 10:e0139810. 10.1371/journal.pone.0139810

Thijs S, Op De Beeck M, Beckers B, Truyens S, Stevens V, Van Hamme JD, Weyens N, and Vangronsveld J. 2017. Comparative Evaluation of Four Bacteria-Specific Primer Pairs for 16S rRNA Gene Surveys. Frontiers in microbiology 8:494-494. 10.3389/fmicb.2017.00494

Thurber VR, Barott KL, Hall D, Liu H, Rodriguez-Mueller B, Desnues C, Edwards RA, Haynes M, Angly FE, Wegley L, and Rohwer FL. 2008. Metagenomic analysis indicates that stressors induce production of herpes-like viruses in the coral Porites compressa. Proc Natl Acad Sci U S A 105:18413-18418. 10.1073/pnas.0808985105

Thurber VR, Haynes M, Breitbart M, Wegley L, and Rohwer F. 2009. Laboratory procedures to generate viral metagenomes. Nat Protoc 4:470-483. 10.1038/nprot.2009.10

Peer) reviewing PDF | (2019:07:39489:2:0:NEW 31 Oct 2019) 
662

663

664

665

666

667

668

669

670

671

672

673

674

675

676

677

678

679

680

681

682

683
Trubl G, Roux S, Solonenko N, Li Y-F, Bolduc B, Rodríguez-Ramos J, Eloe-Fadrosh EA, Rich VI, and Sullivan MB. 2019. Towards optimized viral metagenomes for double-stranded and single-stranded DNA viruses from challenging soils. PeerJ Preprints 7:e27640v27641. 10.7287/peerj.preprints.27640v1

Trubl G, Solonenko N, Chittick L, Solonenko SA, Rich VI, and Sullivan MB. 2016. Optimization of viral resuspension methods for carbon-rich soils along a permafrost thaw gradient. PeerJ 4:e1999. 10.7717/peerj.1999

Velji MI, and Albright LJ. 1993. Improved sample preparation for enumeration of aggregated aquatic substrate bacteria. In: Kemp PF, Sherr BF, Sherr EB, and Cole JJ, eds. Handbook of Methods in Aquatic Microbial Ecology. Boca Raton, Florida: Lewis Publishers, 139142.

Vidakovic L, Singh PK, Hartmann R, Nadell CD, and Drescher K. 2017. Dynamic biofilm architecture confers individual and collective mechanisms of viral protection. Nature Microbiology.

Weitz JS, Stock CA, Wilhelm SW, Bourouiba L, Coleman ML, Buchan A, Follows MJ, Fuhrman JA, Jover LF, Lennon JT, Middelboe M, Sonderegger DL, Suttle CA, Taylor BP, Frede Thingstad T, Wilson WH, and Eric Wommack K. 2015. A multitrophic model to quantify the effects of marine viruses on microbial food webs and ecosystem processes. ISME J 9:1352-1364. 10.1038/ismej.2014.220

Williamson KE, Fuhrmann JJ, Wommack KE, and Radosevich M. 2017. Viruses in Soil Ecosystems: An Unknown Quantity Within an Unexplored Territory. Annual Review of Virology 4:201-219. 10.1146/annurev-virology-101416-041639 


\section{Table 1 (on next page)}

Sample site and biofilm characteristics. 


\begin{tabular}{|c|c|c|c|}
\hline & VDN & VEV & SNG \\
\hline \multirow[t]{2}{*}{ Coordinates } & $46^{\circ} 15^{\prime} 13.5^{\prime \prime} \mathrm{N}$ & $46^{\circ} 30^{\prime} 46.4^{\prime \prime} \mathrm{N}$ & $46^{\circ} 33^{\prime} 23.9^{\prime \prime} \mathrm{N}$ \\
\hline & $7^{\circ} 06^{\prime} 33.9^{\prime \prime} \mathrm{E}$ & $6^{\circ} 54^{\prime} 43.7^{\prime \prime} \mathrm{E}$ & $6^{\circ} 28^{\prime} 55.3^{\prime \prime} \mathrm{E}$ \\
\hline Altitude (m a.s.l.) & 1210 & 766 & 498 \\
\hline Bacterial abundance $\left[\right.$ cells $\mathrm{m}^{-2}$ ] & $2.3 \times 10^{9}$ & $1.8 \times 10^{10}$ & $4.1 \times 10^{11}$ \\
\hline Chlorophyll-a [ $\left.\mu \mathrm{g} \mathrm{cm}^{-2}\right]$ & 0.21 & 0.22 & 1.21 \\
\hline EPS proteins $\left[\mu \mathrm{g} \mathrm{cm}^{-2}\right]$ & 0.05 & 0.04 & 0.24 \\
\hline EPS carbohydrates $\left[\mu \mathrm{g} \mathrm{cm}^{-2}\right]$ & below detection & below detection & 0.08 \\
\hline
\end{tabular}


Table 2 (on next page)

Virome dataset statistics 
raw reads

\begin{tabular}{|c|c|c|c|c|c|}
\hline & GC & & GC & & \\
\hline paired-end & & paired-end & & & Average contig \\
\hline sequences & $\begin{array}{l}\text { content } \\
(\%)\end{array}$ & sequences & $\begin{array}{l}\text { content } \\
(\%)\end{array}$ & Contigs & length (bp) \\
\hline
\end{tabular}

$\begin{array}{lrrrrrr}\text { SNG } & 24388096 & 40.36 & 24172084 & 40.16 & 3698 & 452 \\ \text { VEV } & 22459218 & 40.51 & 22153818 & 40.24 & 11323 & 645 \\ \text { VDN } & 23804190 & 40.68 & 23422408 & 40.21 & 13591 & 676\end{array}$

1 


\section{Figure 1}

Overview of methods for the extraction and purification of viruses from stream biofilms.

First, phages are concentrated using either PEG precipitation or TFF. Different physicochemical extraction procedures were then evaluated for their efficiency. Prior to DNase I digestion, centrifugation and filtration was used to remove cell debris from all samples. Finally, ultracentrifugation in sucrose or $\mathrm{CsCl}$ density gradients was used to purify viruses for downstream molecular analyses. Combinations of all protocols were evaluated for the recovery of VLPS and DNA yield.

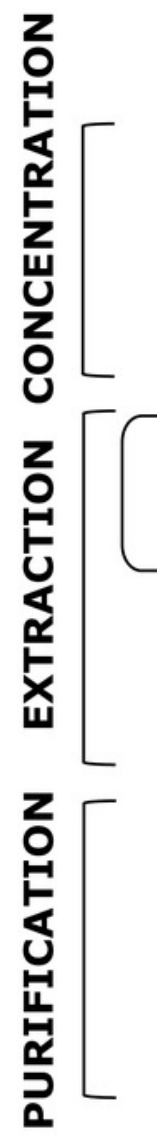

\section{Biofilm sample}

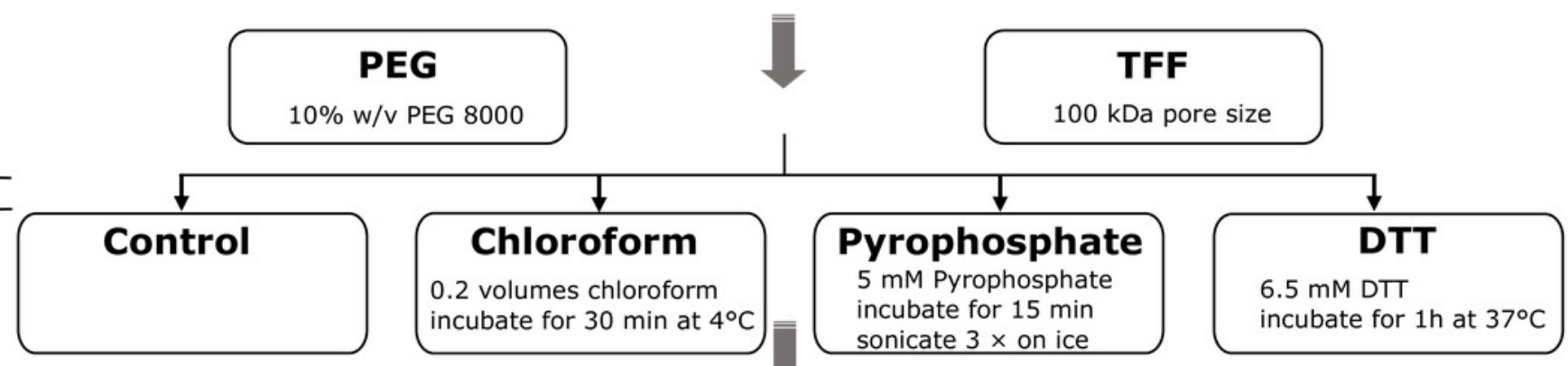

Centrifugation $(3234 \times \mathrm{g})+$ Filtration $(0.8 \mu \mathrm{m}$ and $0.45 \mu \mathrm{m})$

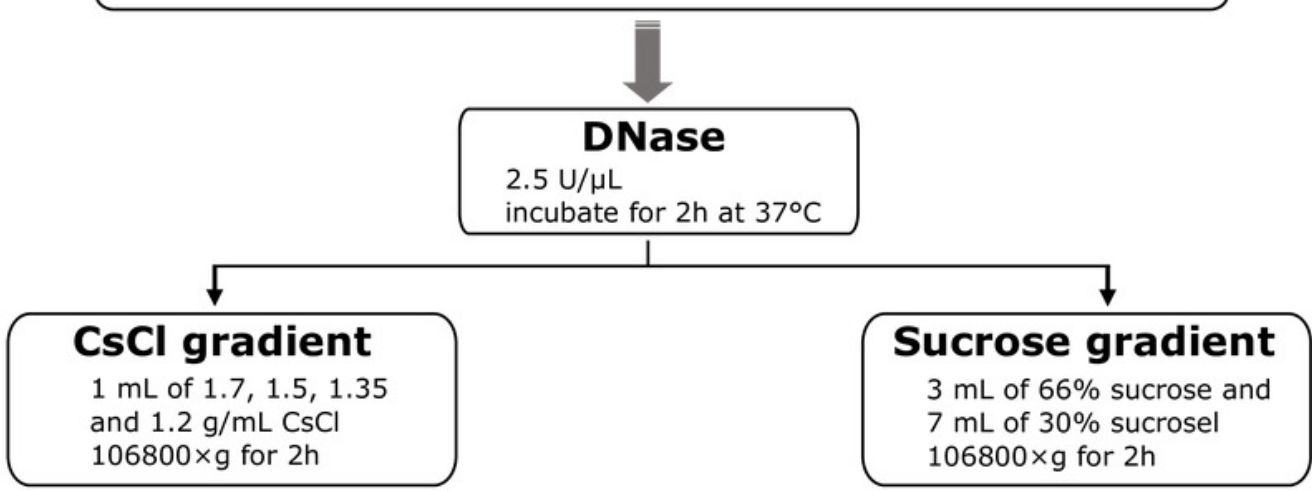


Figure 2

Electron microscopic evidence of virus-like particles in stream biofilm samples.

A large morphological diversity of VLPs, including tailed bacteriophages ( $B, C, D, I)$, lemonshaped, polyhedral (e.g. B, H), spherical and filamentous viruses was observed using TEM.

Some morphologies resembled plant viruses $(E)$ while amorphous structures $(A, G, H)$ could also be membrane vesicles. 

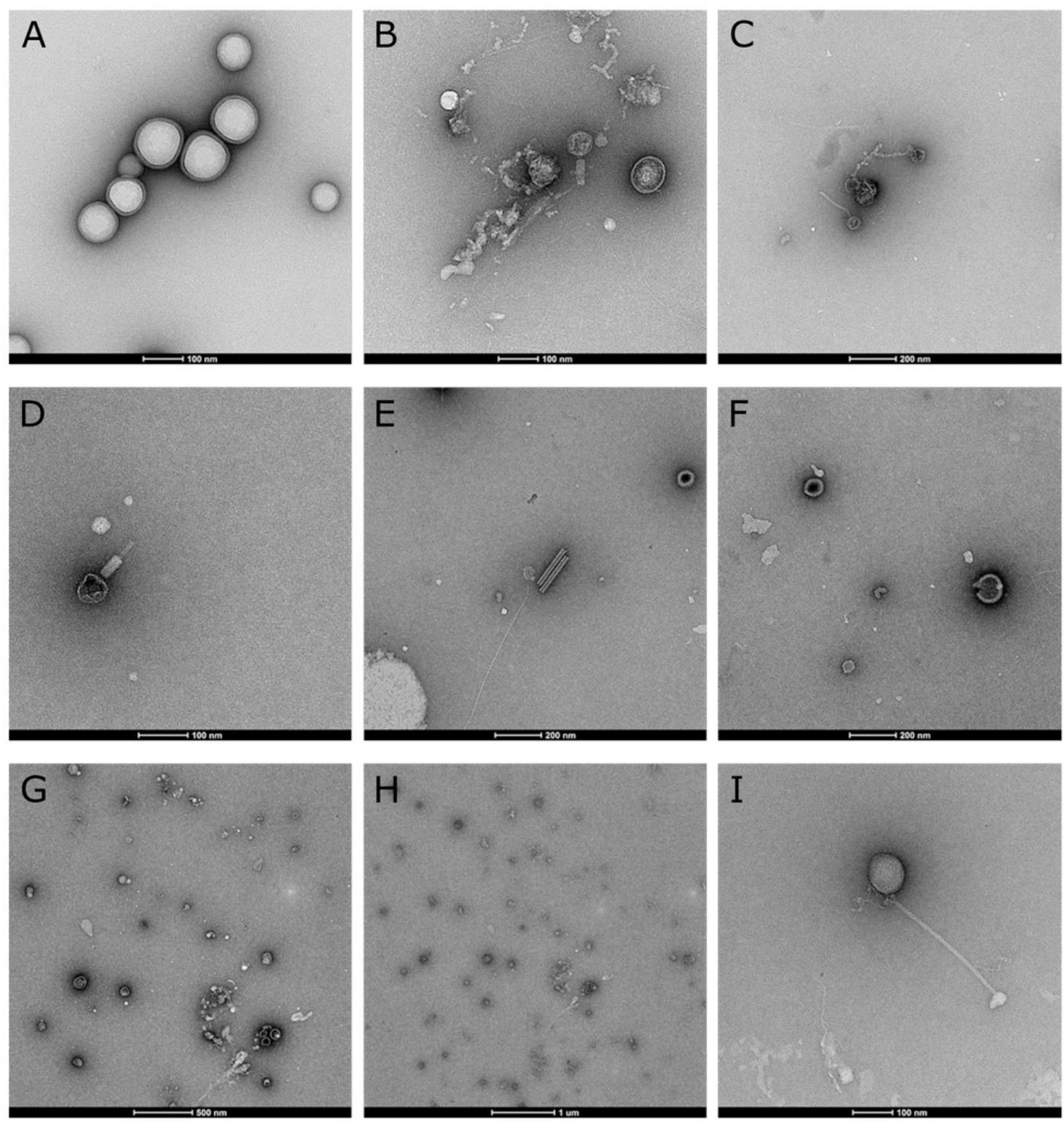
Figure 3

VLP yields of the different combination of methods for the extraction and purification of viruses from stream biofilms.

The boxes show the number of VLPs in replicated subsamples processed with each protocol, the median is given as a horizontal line, hinges correspond to the first and third quartile while whiskers extend to the largest and smallest values counted. In each of the three streams tested, a protocol based on TFF, pyrophosphate in combination with sonication and ultracentrifugation in sucrose gradient yielded significantly higher VLP counts than any other combination of protocols.

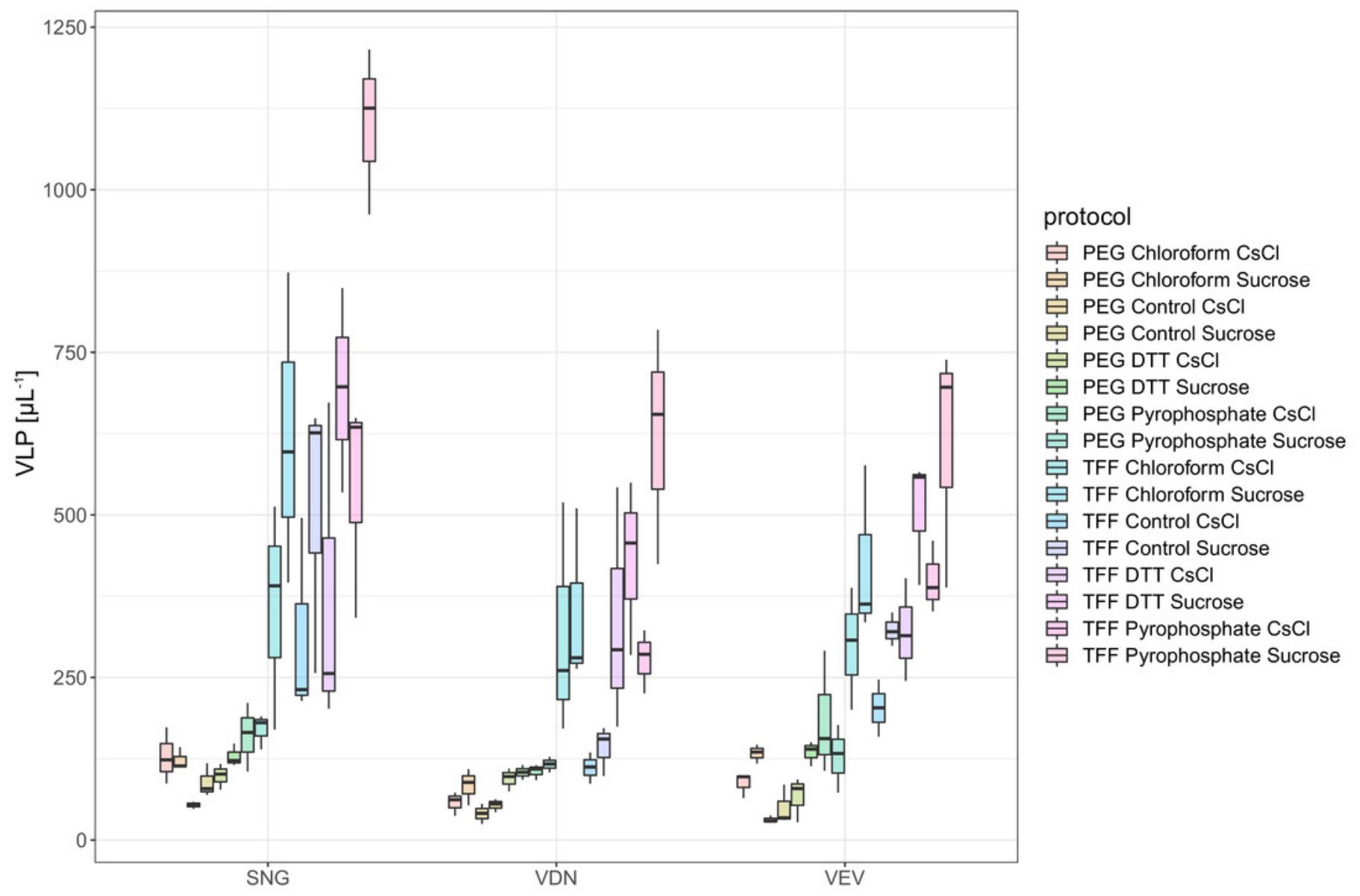




\section{Figure 4}

DNA yields from samples processed with different protocols.

None of the protocols involving PEG precipitation resulted in detectable DNA yields (see DOI:

10.6084/m9.figshare.8943341). Protocols using TFF and either no treatment (control), chloroform, DTT, pyrophosphate in combination with sonication for extraction and either $\mathrm{CsCl}$ or Sucrose gradient ultracentrifugation for purification yielded detectable DNA concentrations. Highest DNA yields were obtained using a combination of TFF, followed by pyrophosphate and sonication and sucrose density gradient ultracentrifugation. Note that although VLP counts were only 1.8 times higher in the best performing protocol in SNG as compared to the other two samples (VDN, VEV), DNA yields in this sample were more than 14 times higher. 


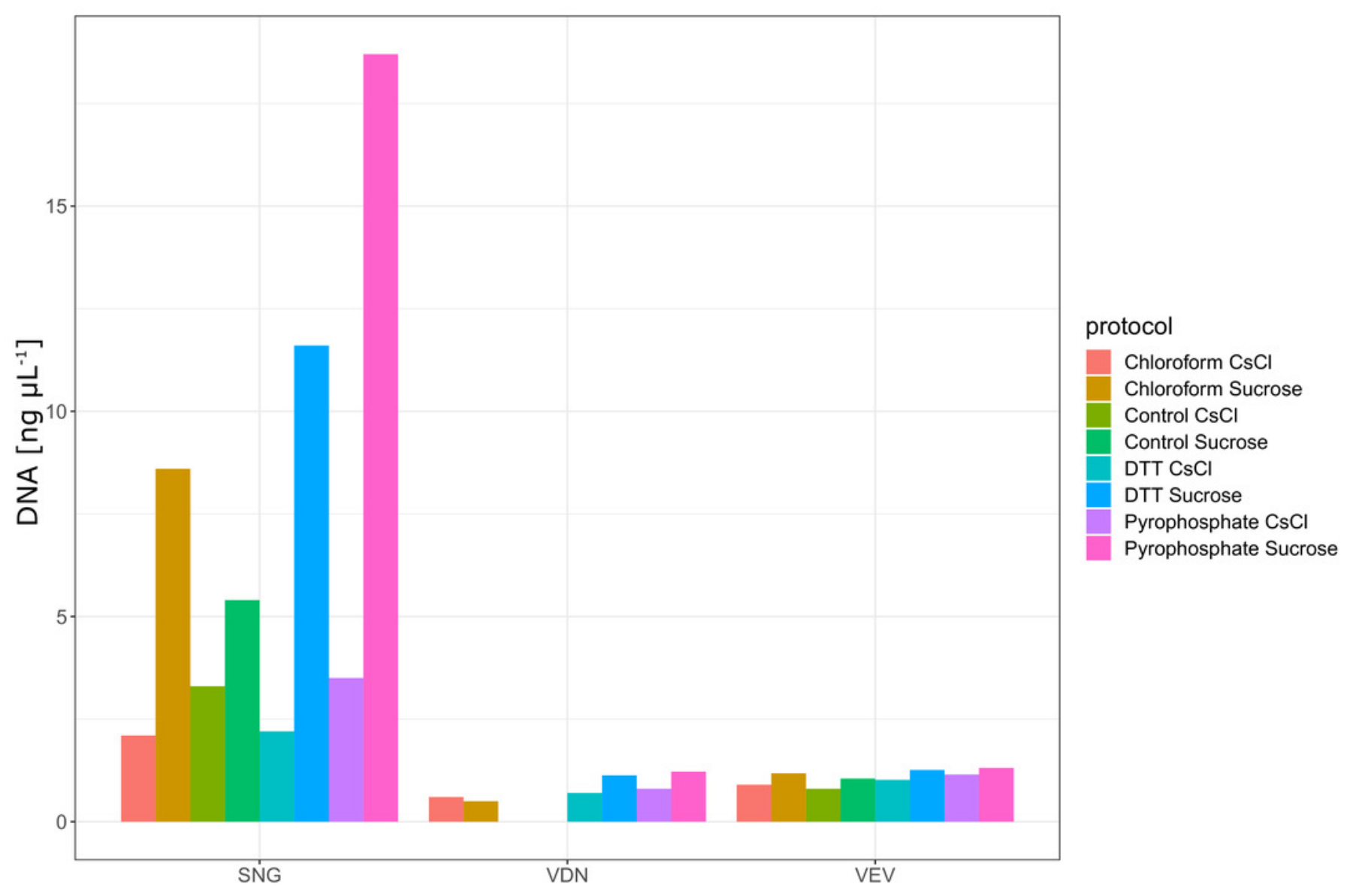




\section{Figure 5}

Stream biofilm virome taxonomic composition.

The relative number of classified contigs among the viromes are shown (A). Stream biofilm viromes were dominated by not further classified members of Siphoviridae and Myoviridae. The relative composition of contigs was similar among the three samples, however, markedly fewer contigs were obtained from SNG than from the other two stream biofilm samples. ssDNA viruses could not be identified among contigs from any of the streams. Panel B provides the average number of reads mapped to classified contigs in the three samples.

A

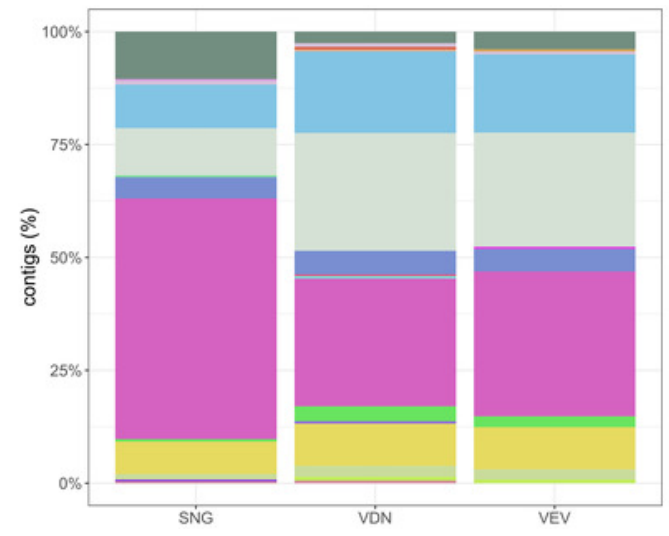

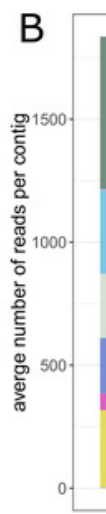

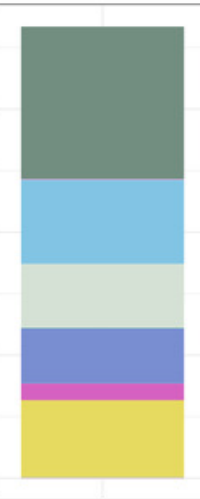

SŃG

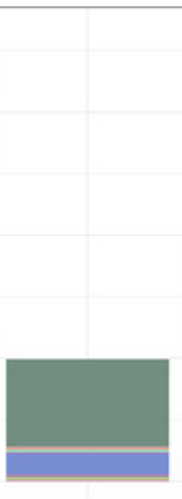

VD́N

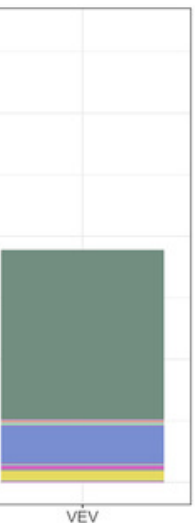

classification

Caudovirales @ Schizot4virus

Cba181virus Sep1virus

Coopervirus - Siphovirid

Cp220virus - T4virus

$\begin{array}{ll}\text { Kayvirus } & \text { Twortvirus } \\ \text { L5virus } & \text { unclassified_bacterial_viruses }\end{array}$

Myoviridae unclassified dsDNA phages

other unclassified_Lambda-like_viruses

P12024virus unclassified_N4likevirus

Phicbkvirus Vequintavirinae 